\title{
Research article \\ Inhibition of E2-induced expression of BRCA1 by persistent organochlorines
}

\author{
Thomas Rattenborg, Irene Gjermandsen and Eva C Bonefeld-Jørgensen
}

Unit of Environmental Biotechnology, Department of Environmental and Occupational Medicine, University of Aarhus, Denmark

Correspondence: Eva C Bonefeld-Jørgensen, Unit of Environmental Biotechnology, Department of Environmental and Occupational Medicine, University of Aarhus, Vennelyst Boulevard 6, DK-8000 Aarhus C, Denmark. Tel: +45 89426162; fax: +45 89426199; e-mail: ebj@mil.au.dk

\begin{abstract}
Background: Environmental persistent organochlorines (POCs) biomagnify in the food chain, and the chemicals are suspected of being involved in a broad range of human malignancies. It is speculated that some POCs that can interfere with estrogen receptor-mediated responses are involved in the initiation and progression of human breast cancer. The tumor suppressor gene BRCA1 plays a role in cell-cycle control, in DNA repair, and in genomic stability, and it is often downregulated in sporadic mammary cancers. The aim of the present study was to elucidate whether POCs have the potential to alter the expression of $B R C A 1$.

Methods: Using human breast cancer cell lines MCF-7 and MDA-MB-231, the effect on BRCA1 expression of chemicals belonging to different classes of organochlorine chemicals (the pesticide toxaphene, 2,3,7,8-tetrachlorodibenzo- $p$-dioxin, and three polychlorinated biphenyls [PCB\#138, PCB\#153 and PCB\#180]) was measured by a reporter gene construct carrying $267 \mathrm{bp}$ of the BRCA1 promoter. A twofold concentration range was analyzed in MCF-7, and the results were supported by northern blot analysis of BRCA1 mRNA using the highest concentrations of the chemicals.

Results: All three polychlorinated biphenyls and 2,3,7,8-tetrachlorodibenzo-p-dioxin reduced 17 $\beta$ estradiol (E2)-induced expression as well as basal reporter gene expression in both cell lines, whereas northern blot analysis only revealed a downregulation of E2-induced BRCA1 mRNA expression in MCF-7 cells. Toxaphene, like E2, induced BRCA1 expression in MCF-7.

Conclusion: The present study shows that some POCs have the capability to alter the expression of the tumor suppressor gene BRCA1 without affecting the cell-cycle control protein $\mathrm{p} 21^{\text {Waf/Cip1. Some }}$ POCs therefore have the potential to affect breast cancer risk.
\end{abstract}

Keywords: $B R C A 1$, estrogen receptor, polychlorinated biphenyls, tetrachlorodibenzo-p-dioxin, toxaphene

\section{Introduction}

The incidence of breast cancer has been increasing steadily over the past 60 years [1], today affecting one in eight women in the United States [2]. Despite tremendous efforts to understand the disease, less than $50 \%$ of all cases are of known etiology such as genetic inheritance, first-degree relatives with breast cancer, and age of menstruation and menopause [3].
A large group of lipophilic organochlorines are found to persist in the environment and to biomagnify through the food chain. This group includes pesticides, polychlorinated biphenyls (PCBs) and polychlorinated dibenzo-dioxins/ polychlorinated dibenzo-furans [4-8]. Many of these compounds can interfere with a wide range of hormonal responses [9-13], including estrogen receptor (ER)mediated responses. Due to their lipophilic nature,

$\mathrm{bp}=$ base pair; $\mathrm{DMEM}=$ Dulbecco's modified Eagle's medium; E2 = 17 $\beta$-estradiol; ER = estrogen receptor; $\mathrm{PCB}=$ polychlorinated biphenyl; $\mathrm{PCR}=$ polymerase chain reaction; $P O C=$ persistent organochlorine; $\operatorname{TCDD}=2,3,7,8$ tetrachlorodibenzo- $p$-dioxin. 
organochlorines accumulate in the adipose tissue, can cross the placenta and are found in the breast milk [14]. The chemicals give rise to life-long exposure and are supposed to disturb early development. There is, however, a great epidemiological disparity in the literature regarding whether an association exists between POCs and breast cancer $[15,16]$.

The breast cancer susceptibility gene, BRCA1 [17], is linked to familial breast cancer [18], and it is found to be downregulated in sporadic breast and ovarian cancers $[19,20]$. Decreased expression of BRCA1 promotes cell proliferation and can cause cell transformation [20,21]. The function of $B R C A 1$ remains unknown, but strong evidence suggests a role in cell-cycle control and DNA repair $[22,23]$. Furthermore, BRCA1 expression is regulated by $17 \beta$-estradiol (E2) $[24,25]$.

To address whether POCs could affect BRCA1 expression, we studied the effect on BRCA1 promoter activity using a transient reporter gene assay and the effect on the BRCA1 mRNA level by northern blot analysis in two human breast cancer cell lines. Furthermore, the effect on the estrogen-responsive gene ( $p S 2)$ was studied, as well the effect on the cell-cycle regulator ( $221^{\mathrm{Waf} / \mathrm{Cip} 1)}$, in order to shed some light on the mechanistic pathways involved.

\section{Materials and methods Chemicals}

Toxaphene (technical mixture; Dr Ehrenstorfer, Augsberg, Germany), 2,3,7,8 tetrachlorodibenzo-p-dioxin (TCDD) (Wellington Laboratories Inc., Guelph, Ontario, Canada), PCB\#138, PCB\#153 and PCB\#180 (Dr Ehrenstorfer), E2 (Sigma-Aldrich Denmark A/S, Copenhagen, Denmark), and ICI 182780 (AstraZeneca, Luton, UK) were used. All compounds were dissolved in ethanol except TCDD, which was dissolved in dimethyl sulfoxide. All concentrations used were nontoxic as revealed by the Cytotoxicity Assay (Promega Corporation, Madison, Wisconsin, USA) and by measurement of total protein (BCA protein reagent; Perbio Science, Helsinborg, Sweden).

\section{Plasmids}

The plasmid pGL12 contains 267 bp, spanning -224 to $+43 \mathrm{bp}$ of the BRCA1 promoter- $\alpha$, subcloned upstream of the luciferase gene [26]. The plasmid pHEO1 contains full-length human ER $\alpha$ cDNA [27]. The plasmid pON249 encodes $\beta$-galactosidase under control of a CMV promoter [28], and was used as the internal standard for transfection efficiencies.

\section{Reporter gene assay}

MCF-7(BUS) cells (ER responsive) and MDA-MB-231 cells (ER nonresponsive) were cultured as described elsewhere $[9,29]$. For experiments, $7.3 \times 10^{5}$ MCF-
7 (BUS) cells or $5 \times 10^{5}$ MDA-MB-231 cells were seeded in six-well trays in DMEM (without phenol red) media containing charcoal-depleted fetal bovine serum (Hyclone Europe, Perbio Science, Erembodegem-Aalst, Belgium). MCF-7(BUS) cells were exposed to the given chemicals and transfected with $1.4 \mu \mathrm{g}$ pGL12 and $0.4 \mu \mathrm{g}$ pON249 using $5 \mu \mathrm{l}$ fugene (Roche, Mannheim, Germany). Cells were harvested in lysis buffer (Roche) 24 hours after exposure and transfection. Luciferase activity was measured using lysis buffer containing $0.5 \mathrm{mM}$ luciferin (Amersham Pharmacia Biotech, Uppsala, Sweden) and $0.5 \mathrm{mM}$ ATP (Sigma). The $\beta$-galactosidase activity was measured by a chemiluminescence kit (Roche). MDAMB-231 cells were exposed and harvested as MCF7 (BUS) but were transfected with $1.5 \mu \mathrm{g}$ pGL12 using $6 \mu \mathrm{l}$ fugene for 48 hours. Cotransfection with ER was carried out with $0.5 \mu \mathrm{g}$ pHEO1.

\section{Total RNA isolation}

On day $1,2.2 \times 10^{6}$ cells were seeded in $75 \mathrm{~cm}^{2}$ culture flasks and grown for 24 hours in fetal calf serum containing media. The cells were starved in serum-free media on day 2 to obtain $\mathrm{G}_{1}$-synchronization, and they were exposed to chemicals in charcoal-depleted fetal bovine serum media on day 3. Total RNA was harvested after 22 hours of chemical exposure (PUREScript; Gentra Systems, Minneapolis, Minnesota, USA).

\section{Northern blot and hybridization}

A BRCA1 probe was produced by PCR on genomic DNA against exon 11 (5'-GAGAGGCATCCAGAAAAGTATCAGG-3' and 5'-CTCTGGGAAAGTATCGCTGTCATG-3') of the BRCA1 gene (882-2216 bp of BRCA1 cDNA [17]). Twenty micrograms of total RNA was used for northern blot analysis (Zeta-probe membrane; Bio-Rad, Hercules, California, USA). The ${ }^{32} \mathrm{P}$-labeled BRCA1 probe was made by random primed labeling (Megaprime; Amersham Pharmacia Biotech), and was hybridized overnight at $42^{\circ} \mathrm{C}$ in $50 \%$ formamide (as described by the manufacturer). The $p S 2$-specific probe and the internal control (the GADPH probe) were used as described elsewhere $[13,29]$. The blots were visualized by a Phosphorlmager and quantified with ImageQuant (Molecular Dynamics Amersham Biosciences, Sunnyvale, California, USA).

\section{p21 Waf/Cip1 protein level}

The p21 Waf/Cip1 protein was quantified on 24 hour exposure of MCF-7(BUS) to the given chemicals using the Waf1 Elisa kit (Oncogene Research Products, San Diego, California, USA).

\section{Statistics}

Statistical analysis was carried out in the Microsoft Excel standard diagram for independent samples test. $P$ values were calculated using the two-tailed $t$-test two sample, assuming unequal variances. 


\section{Results}

\section{Reporter gene assay}

The dose-response effects of the chemicals on the BRCA1 promoter-luciferase construct (pGL12) in MCF7(BUS) are presented in Table 1. In MCF-7(BUS), TCDD, $\mathrm{ICl} 182780$, and the PCBs all significantly reduced the basal (ethanol) and the E2-induced promoter activity at the maximum concentrations tested (TCDD, $100 \mathrm{nM} ; \mathrm{ICl}$ 182780 and PCBs, $10 \mu \mathrm{M})$. However, $10 \mu \mathrm{M}$ toxaphene significantly induced basal promoter activity. TCDD and the pure ER antagonist ICI 182780 had the potential to decrease basal and E2-induced promoter activity at 100 and $10 \mathrm{pM}$, respectively, while PCB\#138 had the potential to decrease E2-induced promoter activity at $100 \mathrm{pM}$. All chemicals (TCDD, $10 \mathrm{nM}$; ICl 182780 and PCBs, $10 \mu \mathrm{M})$ significantly reduced the $B R C A 1$-promoter activity in MDA-MB-231. Cotransfection of the ER into MDA-MB231 showed that the BRCA1 promoter is indeed induced by E2 (Table 1); however, only twofold induction occurred compared with the fivefold induction in MCF-7(BUS).

\section{Northern blot analysis}

To assess whether the findings in the reporter gene assay are also valid for genomic BRCA1 mRNA expression, northern blot analysis was carried out to measure the effect on the BRCA1 mRNA level with each compound at $10 \mu \mathrm{M}$, except for TCDD at $10 \mathrm{nM}$ and $\mathrm{ICl} 182780$ at $100 \mathrm{nM}$. Figure 1 shows a Phosphorlmager image of $B R C A 1, p S 2$ and $G A D P H$ hybridizations to a northern blot. The analyzed data for BRCA1 are presented in Fig. 2. E2 induced BRCA1 mRNA expression twofold, and all compounds except toxaphene significantly decreased the E2-induced BRCA1 expression in MCF-7. Toxaphene increased the basal BRCA1 mRNA expression, while ICl 182780 downregulated basal and E2induced expression. No effect of the chemicals on BRCA1 mRNA expression was measured in the ER nonresponsive MDA-MB-231 cells.

To further address whether ER mediates the observed deregulation of BRCA1 mRNA, expression of the ER responsive gene $p S 2$ was measured in parallel (Fig. 3a). A 2.5-fold induction of $p S 2$ by E2 was observed, and a twofold induction by toxaphene confirmed its ER agonistic behavior. ICl 182780 significantly decreased basal and E2-induced pS2 expression, whereas TCDD significantly reduced E2-induced $p S 2$ mRNA expression. The three $\mathrm{PCB}$ did not significantly affect the $p S 2$ expression.

\section{p21 Waf/Cip1 study}

To address whether the observed response could be a direct consequence of changes in cell-cycle regulation, we determined the effect of the POCs on the negative cell-cycle regulator $\mathrm{p} 21_{\mathrm{Waf} / \mathrm{Cip} 1 .}$ As shown in Fig. 3b, the POCs generally did not affect the $\mathrm{p} 21^{\text {Waf/Cip } 1}$ protein level. Toxaphene, however, decreased the basal p21Waf/Cip1 level like E2. Similar to ICl 182780, TCDD elicited an antiestrogenic effect on cotreatment with E2.

\section{Discussion}

BRCA1 mRNA expression is frequently downregulated in sporadic breast and ovarian cancers $[19,20]$. This altered regulation is generally not correlated with mutations within the gene [30]. The present study demonstrated that POCs in vitro had the potential to deregulate BRCA1 promoter activity and mRNA expression in human breast cancer cell lines. Using an E2-responsive construct carrying the key positive regulatory element of the BRCA1 promoter upstream of the luciferase gene [26,31], we found that TCDD, PCB\#138, PCB\#153, and PCB\#180 can downregulate the basal as well as the E2-induced BRCA1 promoter activity in both the ER-positive cell line (MCF-7(BUS)) and in the ER-negative cell line (MDA-MB231). However, toxaphene induced basal promoter activity (Table 1).

The inhibiting effect of TCDD and the three PCBs were confirmed by northern blot analysis on the E2-induced BRCA1 mRNA level in MCF-7 (Fig. 2). E2 induced the BRCA1 mRNA level twofold, and the observed estrogenlike activity of toxaphene supports earlier findings [32,33]. At concentrations of $10 \mu \mathrm{M}$, the three PCBs had the capacity to downregulate both basal and E2-induced $B R C A 1$ promoter activity, while they only decreased the E2-induced BRCA1 mRNA level. Furthermore, the PCBs antagonized E2-induced pS2 mRNA expression, but it was not statistically significant (Fig. 3a). The antiestrogenic potential of the three PCBs mediated via the $\mathrm{ER}$, causing an antiproliferative effect in MCF-7, has previously been published by our laboratory [9].

Jeffy et al. found BRCA1 to be downregulated by benzo[a]pyrene in an ER-dependent fashion, probably through an aryl hydrocarbon receptor-mediated pathway [34]. Using RT-PCR, however, Jeffy et al. did not observe TCDD to downregulate BRCA1 in MCF-7. In the present study, TCDD significantly reduced both BRCA1 promoter activity as well as E2-induced BRCA1 (Fig. 2) and $p S 2$ mRNA expression in MCF-7 (Fig. 3a; see [13]).

All the POCs except toxaphene significantly decreased E2-induced BRCA1 mRNA expression in MCF-7. No effect was measured on the mRNA level in MDA-MB-231 (Fig. 2), which indicates the mechanism of action to be via the ER. In MDA-MB-231, however, the POCs also decreased the BRCA1 promoter activity, suggesting that other pathways than the ER-mediated pathway should be considered. We have shown that the three PCBs in MCF7 (BUS) are antiproliferative and anti-estrogenic at $10 \mu \mathrm{M}$ [9], as has also been reported for TCDD [34], whereas toxaphene has been shown to increase MCF-7 proliferation $[33,35]$. In the present study, the negative cell-cycle 
Table 1

\begin{tabular}{|c|c|c|c|c|c|c|}
\hline MCF-7(BUS) & Tox.Tech. & $\begin{array}{l}\text { Tox.Tech. + } \\
100 \text { pM E2 }\end{array}$ & ICl 182780 & $\begin{array}{c}\mathrm{ICl} 182780+ \\
100 \text { pM E2 }\end{array}$ & TCDD & $\begin{array}{c}\text { TCDD + } \\
100 \mathrm{pM} \mathrm{E2}\end{array}$ \\
\hline Control & $18 \pm 2.9$ & $100 \pm 11.8$ & $18 \pm 0.3$ & $100 \pm 6.3$ & $18 \pm 0.8$ & $100 \pm 8.4$ \\
\hline $10 \mu \mathrm{M}$ & $36 \pm 8.3^{*}$ & $59 \pm 8.6^{*}$ & $5 \pm 1.1^{*}$ & $8 \pm 3.4^{*}$ & n.d. & n.d. \\
\hline $1 \mu \mathrm{M}$ & $20 \pm 2.5$ & $96 \pm 25.2$ & $7 \pm 0.5^{\star}$ & $7 \pm 0.6^{*}$ & n.d. & n.d. \\
\hline $100 \mathrm{nM}$ & $20 \pm 6.8$ & $102 \pm 16.8$ & $5 \pm 0.4^{*}$ & $5 \pm 1.7^{*}$ & $7 \pm 0.9^{*}$ & $46 \pm 4.6^{*}$ \\
\hline $10 \mathrm{nM}$ & $24 \pm 8.1$ & $95 \pm 7.4$ & $5 \pm 0.7^{\star}$ & $8 \pm 2.4^{*}$ & $7 \pm 0.8^{*}$ & $33 \pm 2.6^{*}$ \\
\hline $1 \mathrm{nM}$ & $23 \pm 8.1$ & $88 \pm 21.8$ & $5 \pm 0.7^{*}$ & $46 \pm 10.8^{*}$ & $8 \pm 1.3^{*}$ & $39 \pm 3.5^{\star}$ \\
\hline $100 \mathrm{pM}$ & $24 \pm 9.3$ & $108 \pm 11.4$ & $9 \pm 0.3^{*}$ & $81 \pm 5.0^{*}$ & $14 \pm 2.5^{\star}$ & $66 \pm 12.6^{*}$ \\
\hline $10 \mathrm{pM}$ & $17 \pm 1.7$ & $112 \pm 4.2$ & $12 \pm 0.8^{*}$ & $109 \pm 25.1$ & $16 \pm 4.0$ & $110 \pm 24.1$ \\
\hline $1 \mathrm{pM}$ & $21 \pm 3.4$ & $92 \pm 18.9$ & $15 \pm 2.3$ & $101 \pm 55.8$ & $25 \pm 6.7$ & $107 \pm 13.8$ \\
\hline MCF-7(BUS) & PCB\#138 & $\begin{array}{c}\text { PCB\#138 + } \\
100 \text { pM E2 }\end{array}$ & PCB\#153 & $\begin{array}{c}\text { PCB\#153 + } \\
100 \text { pM E2 }\end{array}$ & PCB\#180 & $\begin{array}{c}\text { PCB\#180 + } \\
100 \text { pM E2 }\end{array}$ \\
\hline Control & $18 \pm 3.0$ & $100 \pm 7.8$ & $18 \pm 2.1$ & $100 \pm 6.9$ & $18 \pm 1.7$ & $100 \pm 12.7$ \\
\hline $10 \mu \mathrm{M}$ & $7 \pm 1.2^{*}$ & $59 \pm 14.9^{*}$ & $8 \pm 0.7^{*}$ & $75 \pm 9.0^{*}$ & $9 \pm 3.5^{*}$ & $70 \pm 11.5^{*}$ \\
\hline $1 \mu \mathrm{M}$ & $17 \pm 1.5$ & $81 \pm 19.5$ & $16 \pm 3.5$ & $92 \pm 17.2$ & $13 \pm 4.0$ & $105 \pm 11.7$ \\
\hline $100 \mathrm{nM}$ & $16 \pm 1.7$ & $90 \pm 4.9^{*}$ & $21 \pm 0.9$ & $97 \pm 12.9$ & $16 \pm 1.4$ & $110 \pm 24.7$ \\
\hline $10 \mathrm{nM}$ & $17 \pm 3.9$ & $82 \pm 10.5^{\star}$ & $22 \pm 4.4$ & $113 \pm 10.6$ & $19 \pm 5.4$ & $107 \pm 28.9$ \\
\hline $1 \mathrm{nM}$ & $19 \pm 3.0$ & $87 \pm 4.0^{*}$ & $20 \pm 5.1$ & $131 \pm 28.9$ & $23 \pm 7.9$ & $94 \pm 10.2$ \\
\hline $100 \mathrm{pM}$ & $18 \pm 4.1$ & $88 \pm 6.5^{\star}$ & $21 \pm 6.4$ & $95 \pm 16.5$ & $17 \pm 6.4$ & $108 \pm 31.1$ \\
\hline $10 \mathrm{pM}$ & $19 \pm 2.2$ & $85 \pm 21.2$ & $22 \pm 0.9$ & $112 \pm 26.7$ & $21 \pm 7.4$ & $112 \pm 11.3$ \\
\hline $1 \mathrm{pM}$ & $24 \pm 5.3$ & $86 \pm 20.3$ & $19 \pm 6.2$ & $111 \pm 9.5$ & $16 \pm 5.0$ & $109 \pm 21.2$ \\
\hline MDA-MB-231 & Control & $\begin{array}{l}\text { Tox.Tech. } \\
(10 \mu \mathrm{M})\end{array}$ & $\begin{array}{c}\text { TCDD } \\
(10 \mathrm{nM})\end{array}$ & $\begin{array}{l}\text { PCB\#138 } \\
(10 \mu \mathrm{M})\end{array}$ & $\begin{array}{l}\text { PCB\#153 } \\
(10 \mu \mathrm{M})\end{array}$ & $\begin{array}{l}\text { PCB\#180 } \\
(10 \mu \mathrm{M})\end{array}$ \\
\hline pGL12 & $93 \pm 19.3$ & $21 \pm 8.1^{*}$ & $65 \pm 11.5^{\star}$ & $35 \pm 1.3^{*}$ & $50 \pm 10.6^{*}$ & $49 \pm 7.0^{\star}$ \\
\hline $\begin{array}{l}\text { pGL12 + } \\
10 \text { nM E2 }\end{array}$ & $100 \pm 15.0$ & $21 \pm 6.6^{*}$ & $69 \pm 8.6^{*}$ & $32 \pm 6.9^{*}$ & $53 \pm 6.0^{*}$ & $44 \pm 5.6^{\star}$ \\
\hline pGL12/ER & $57 \pm 10.4$ & $35 \pm 11.6^{*}$ & $55 \pm 15.5$ & $45 \pm 10.6$ & $46 \pm 12.8$ & $48 \pm 13.5$ \\
\hline $\begin{array}{l}\text { pGL12/ER + } \\
10 \mathrm{nM} \mathrm{E2}\end{array}$ & $100 \pm 13.8$ & $37 \pm 21.3^{\star}$ & $74 \pm 35.8$ & $65 \pm 23.9^{*}$ & $60 \pm 24.5^{\star}$ & $58 \pm 36.5$ \\
\hline
\end{tabular}

All values are corrected with $\beta$-galactosidase values (MCF-7(BUS)) or protein (MDA-MB-231) and then normalized to 17 $\beta$-estradiol (E2)-induced cells (set to 100). The data are mean \pm standard deviations of at least five or six measurements from two independent experiments. pGL12/ER, cotransfection with the pHEO1-expressing estrogen receptor alpha; Tox.Tech., toxaphene (technical mixture); TCDD, 2,3,7,8 tetrachlorodibenzo- $p$ dioxin; PCB, polychlorinated biphenyl. * $P<0.05$ relative to the given control (ethanol/DMSO or E2).

regulator p21 Waf/Cip1 was not affected by the PCBs, while the effect of E2 was as expected [36] and toxaphene decreased the p21Waf/Cip1 protein level. ICI 182780 and TCDD increased the E2 reduced level to its normal level (Fig. 3b). This suggests that the deregulation of BRCA1 observed in this study is not a simple consequence of altered cell-cycle regulation. Since the reporter gene assay also showed an effect of the POCs in MDA-MB-231, further research is needed to elucidate the pathways of the BRCA1 deregulation as well as the involvement of other regulatory sites outside of the $267 \mathrm{bp}$ key regulatory element of the BRCA1 promoter cloned in the $\mathrm{pGL}-12$ vector. In addition, a possible effect on BRCA1 expression of the chemicals in combination and in a mimic of the concentrations found in the adipose tissue should be addressed. 


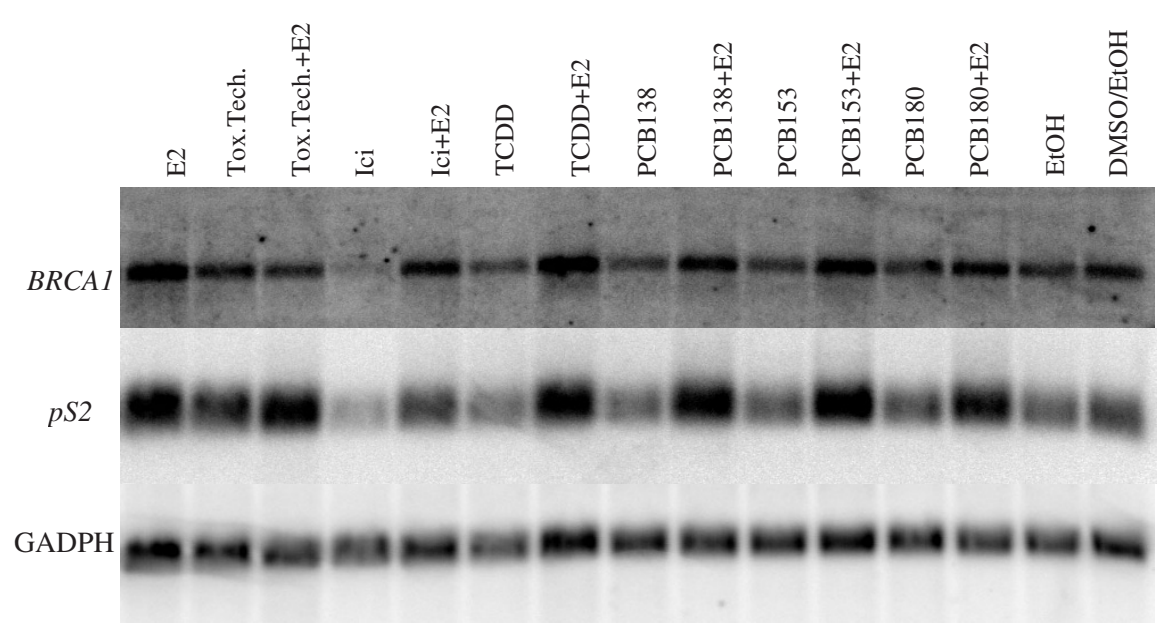

Phosphorlmager images of hybridizations with BRCA1 (7.8 kb), pS2 (500 bp), and GADPH (1.3 kb) probes against the same northern blot membrane with $20 \mu \mathrm{g} / \mathrm{lane}$ total RNA from MCF-7. Concentrations of the chemicals are as shown in Fig. 2. The filter represents only one experiment. The collective data are presented in Figs 2 and 3. After hybridization with BRCA1, the filter was stripped and rehybridized with $p S 2$ and then with GADPH. MDA-MB-231 data are not shown. E2, 17ß-estradiol; Tox.Tech., toxaphene (technical mixture); Ici, ICl 182780; TCDD, 2,3,7,8 tetrachlorodibenzo-p-dioxin; PCB, polychlorinated biphenyl; EtOH, ethanol; DMSO, dimethyl sulfoxide.

Figure 2

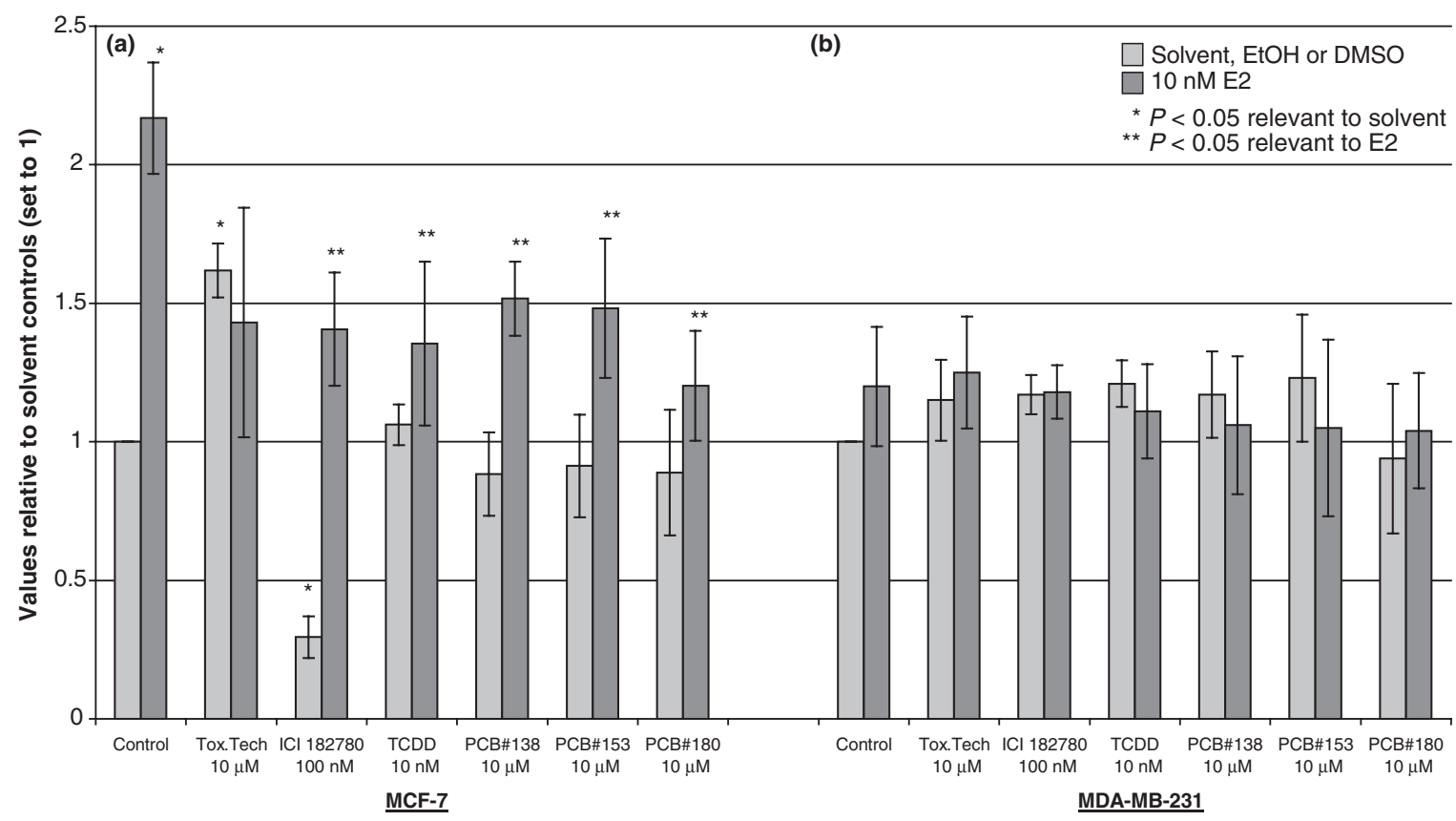

Effect of persistent organochlorines on BRCA1 mRNA expression in (a) MCF-7 and (b) MDA-MB-231. All values are normalized to the internal control (GADPH) and then related to the solvent control (set to 1). Dark bars indicate cotreatment of $17 \beta$-estradiol and the given compound. ${ }^{*} P<0.05$ compared with solvent-treated cells, ${ }^{* *} P<0.05$ compared with $17 \beta$-estradiol $(10 \mathrm{nM}$ )-exposed cells. Data are presented as mean \pm standard deviation of at least three independent experiments. E2, $17 \beta$-estradiol; Tox.Tech., toxaphene (technical mixture); TCDD, 2,3,7,8 tetrachlorodibenzo-p-dioxin; PCB, polychlorinated biphenyl; EtOH, ethanol; DMSO, dimethyl sulfoxide. 


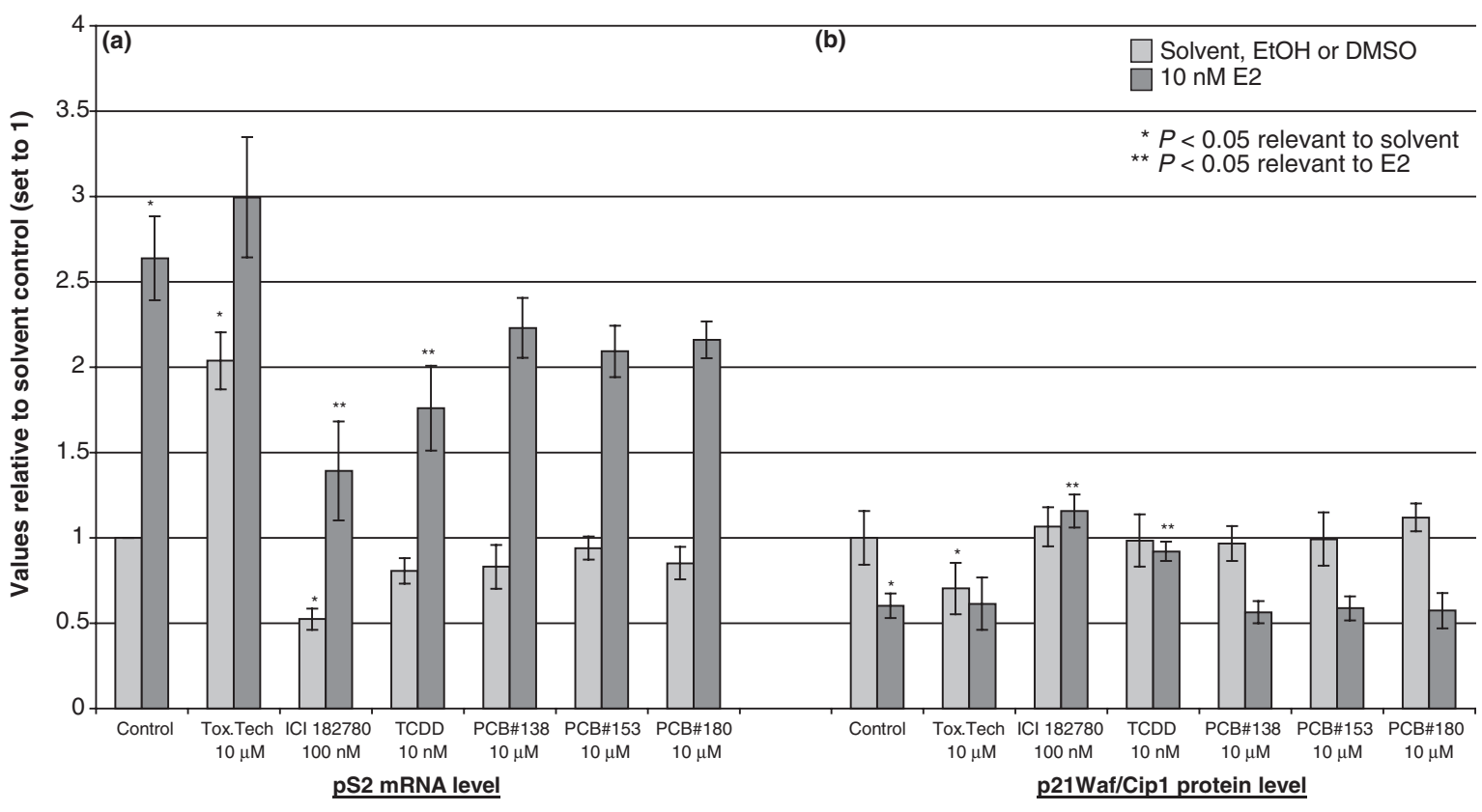

Effect of persistent organochlorines on (a) pS2 mRNA expression in MCF-7 and (b) p21 Waf1/Cip1 in MCF-7(BUS). The $p S 2$ data are normalized to GADPH and the related to solvent control (set to 1). Dark bars indicate cotreatment of $17 \beta$-estradiol and the given compound. ${ }^{*} P<0.05$ compared with solvent-treated cells, ${ }^{* *} P<0.05$ compared with $17 \beta$-estradiol $(10 \mathrm{nM})$-exposed cells. Data are presented as mean \pm standard deviation of at least three independent experiments (pS2) or two independent experiments assayed in duplicate (p21 Waf1/Cip1). E2, 17ß-estradiol; Tox.Tech., toxaphene (technical mixture); TCDD, 2,3,7,8 tetrachlorodibenzo-p-dioxin; PCB, polychlorinated biphenyl; EtOH, ethanol; DMSO, dimethyl sulfoxide.

\section{Conclusion}

It was found that TCDD, PCB\#138, PCB\#153, and PCB\#180 decreased E2-induced BRCA1 promoter activity and mRNA expression in human breast cancer cell lines. Toxaphene induced the basal BRCA1 expression, probably via inducing cell proliferation since it was found to downregulate the cell-cycle protein $\mathrm{p} 21^{\mathrm{Wa} / / \mathrm{Cip} 1}$. The presented data show that the ER is likely to play an essential role in the deregulation of $B R C A 1$, but the data indicate a possible involvement of other pathways as well. The effect of these POCs on BRCA1 expression may, however, for a large part be a consequence of their anti-estrogenic, and hence antiproliferative, effect. By deregulating BRCA1, therefore, as has been found in sporadic breast cancers, the POCs could impair the DNA repair machinery, the cellcycle control and the stress-induced apoptosis [37]. POCs consequently could affect the overall risk of breast cancer.

\section{Acknowledgements}

The authors would like to thank Birgitte $S$ Jacobsen for indispensable technical support. pGL12 was a kind gift from E Solomon (UK), and P Chambon (France) provided pHEO1 and the pS2 probe.

\section{References}

1. Davis DL, Bradlow HL: Can environmental estrogens cause breast cancer? Sci Am 1995, 273:167-172.
2. Chen X, Danes C, Lowe M, Herliczek TW, Keyomarsi K: Activation of the estrogen-signaling pathway by p21(WAF1/CIP1) in estrogen receptor-negative breast cancer cells. J Natl Cancer Inst 2000, 92:1403-1413.

3. Johnson-Thompson MC, Guthrie J: Ongoing research to identify environmental risk factors in breast carcinoma. Cancer 2000, 88(5 suppl):1224-1229.

4. Kidd KA, Schindler DW, Muir DCG, Lockhart WL, Hesslein RH: High concentration of Toxaphene in fishes from a subarctic lake. Science 1995, 269:240-242.

5. Mulvad G, Pedersen HS, Hansen JC, Dewailly E, Jul E, Pederson MB, Bjerregaard P, Malcom GT, Deguchi Y, Middaugh JP: Exposure of Greenlandic Inuit to organochlorines and heavy metals through the marine food-chain: an international study. Sci Total Environ 1996, 186:137-139.

6. Wolff MS, Toniolo PG: Environmental organochlorine exposure as a potential etiologic factor in breast cancer. Environ Health Perspect 1995, 103(suppl 7):141-145.

7. Fromberg A, Cleemann M, Carlsen L: Review on persistent organic pollutants in the environment of Greenland and Faroe Islands. Chemosphere 1999, 38:3075-3093.

8. Schecter A, Stanley J, Boggess K, Masuda Y, Mes J, Wolff M, Furst P, Furst C, Wilson Yang K, Chisholm B: Polychlorinated biphenyl levels in the tissues of exposed and nonexposed humans. Environ Health Perspect 1994, 102(suppl 1):149-158.

9. Bonefeld-Jorgensen EC, Andersen HR, Rasmussen TH, Vinggaard AM: Effect of highly bioaccumulated polychlorinated biphenyl congeners on estrogen and androgen activity. Toxicology 2001, 158:141-153.

10. Carpenter DO, Arcaro KF, Bush B, Niemi WD, Pang S, Vakharia DD: Human health and chemical mixtures: an overview. Environ Health Perspect 1998, 106(suppl 6):1263-1270.

11. Carpenter DO: Polychlorinated biphenyls and human health. Int J Occup Med Environ Health 1998, 11:291-303. 
12. Porterfield SP: Thyroidal dysfunction and environmental chemicals - potential impact on brain development [in process citation]. Environ Health Perspect 2000, 108(suppl 3):433-438.

13. Bonefeld Jorgensen EC, Autrup H, Hansen JC: Effect of toxaphene on estrogen receptor functions in human breast cancer cells. Carcinogenesis 1997, 18:1651-1654.

14. Arctic Monitoring and Assessment Programme: AMAP Assessment Report: Arctic Pollution Issues. Oslo: Arctic Monitoring and Assessment Programme; 1998.

15. Safe SH: Endocrine disruptors and human health - is there a problem? An update. Environ Health Perspect 2000, 108:487493.

16. Aronson KJ, Miller AB, Woolcott CG, Sterns EE, McCready DR, Lickley LA, Fish EB, Hiraki GY, Holloway C, Ross T, Hanna WM, SenGupta SK, Weber JP: Breast adipose tissue concentrations of polychlorinated biphenyls and other organochlorines and breast cancer risk. Cancer Epidemiol Biomarkers Prev 2000, 9: $55-63$

17. Miki Y, Swensen J, Shattuck Eidens D, Futreal PA, Harshman K, Tavtigian S, Liu Q, Cochran C, Bennett LM, Ding W, Bell R, Rosenthal J, Hussey C, Tran T, McClure M, Fryre C, Hattier T, Phelps R, Haugen-Strano A, Katcher H, Yakumo K, Gholami Z, Shaffer D, Stone S, Bayer S, Wray C, Bogden R, Dayananth P, Ward J, Tonin P, Narod S, Bristow PK, Norris FH, Helvering L, Morrison P, Rosteck P, Lai M, Barett JC, Lewis C, Neuhausen S, Cannon-Albright L, Goldgar D, Wiseman R, Kamb A, Skolnick $\mathrm{MH}$ : A strong candidate for the breast and ovarian cancer susceptibility gene BRCA1. Science 1994, 266:66-71.

18. Hall JM, Lee MK, Newman B, Morrow JE, Anderson LA, Huey B, King MC: Linkage of early-onset familial breast cancer to chromosome 17q21. Science 1990, 250:1684-1689.

19. Zheng W, Luo F, Lu JJ, Baltayan A, Press MF, Zhang ZF, Pike MC: Reduction of BRCA1 expression in sporadic ovarian cancer [see comments]. Gynecol Oncol 2000, 76:294-300.

20. Thompson ME, Jensen RA, Obermiller PS, Page DL, Holt JT: Decreased expression of BRCA1 accelerates growth and is often present during sporadic breast cancer progression. Nat Genet 1995, 9:444-450.

21. Rao VN, Shao N, Ahmad M, Reddy ES: Antisense RNA to the putative tumor suppressor gene BRCA1 transforms mouse fibroblasts. Oncogene 1996, 12:523-528.

22. Gowen LC, Avrutskaya AV, Latour AM, Koller BH, Leadon SA: BRCA1 required for transcription-coupled repair of oxidative DNA damage. Science 1998, 281:1009-1012.

23. MacLachlan TK, Somasundaram $K$, Sgagias $M$, Shifman $Y$, Muschel RJ, Cowan KH, El-Deiry WS: BRCA1 effects on the cell cycle and the DNA damage response are linked to altered gene expression. J Biol Chem 2000, 275:2777-2785.

24. Romagnolo D, Annab LA, Thompson TE, Risinger JI, Terry LA, Barrett JC, Afshari CA: Estrogen upregulation of BRCA1 expression with no effect on localization. Mol Carcinogen 1998, 22:102-109.

25. Gudas JM, Nguyen H, Li T, Cowan KH: Hormone-dependent regulation of BRCA1 in human breast cancer cells. Cancer Res 1995, 55:4561-4565.

26. $\mathrm{Xu} C F$, Chambers JA, Solomon E: Complex regulation of the BRCA1 gene. J Biol Chem 1997, 272:20994-20997.

27. Green $S$, Walter $P$, Kumar V, Krust A, Bornert JM, Argos $P$, Chambon P: Human oestrogen receptor cDNA: sequence, expression and homology to v-erb-A. Nature 1986, 320:134139.

28. Cherrington JM, Mocarski ES: Human cytomegalovirus ie1 transactivates the alpha promoter-enhancer via an 18-basepair repeat element. J Virol 1989, 63:1435-1440.

29. Jorgensen EC, Autrup $H$ : Autoregulation of human CYP1A1 gene promotor activity in HepG2 and MCF-7 cells. Carcinogenesis 1996, 17:435-441.

30. Ozcelik H, To MD, Couture J, Bull SB, Andrulis IL: Preferential allelic expression can lead to reduced expression of BRCA1 in sporadic breast cancers. Int J Cancer 1998, 77:1-6.

31. Thakur S, Croce CM: Positive regulation of the BRCA1 promoter. J Biol Chem 1999, 274:8837-8843.

32. Stelzer A, Chan HM: The relative estrogenic activity of technical toxaphene mixture and two individual congeners. Toxicology 1999, 138:69-80.

33. Soto AM, Chung KL, Sonnenschein C: The pesticides endosulfan, toxaphene, and dieldrin have estrogenic effects on human estrogen-sensitive cells. Environ Health Perspect 1994, 102:380-383.

34. Jeffy BD, Schultz EU, Selmin O, Gudas JM, Bowden GT, Romagnolo $D$ : Inhibition of BRCA-1 expression by benzo[a]pyrene and its diol epoxide. Mol Carcinogen 1999, 26:100-118.

35. Soto AM, Sonnenschein C, Chung KL, Fernandez MF, Olea N, Serrano FO: The E-SCREEN assay as a tool to identify estrogens: an update on estrogenic environmental pollutants. Environ Health Perspect 1995, 103(suppl 7):113-122.

36. Prall OW, Carroll JS, Sutherland RL: A low abundance pool of nascent p21WAF1/Cip1 is targeted by estrogen to activate cyclin $E^{*}$ Cdk2. J Biol Chem 2001, 276:45433-45442.

37. Thangaraju M, Kaufmann SH, Couch FJ: BRCA1 facilitates stress-induced apoptosis in breast and ovarian cancer cell lines. J Biol Chem 2000, 275:33487-33496. 